\title{
Vegetation of the Willa Cather Memorial Prairie
}

\author{
ROBERT A. NICHOLSON AND MICHAEL G. MARCOTTE
}

\begin{abstract}
The purpose of this study was to analyze the interrelationships of the Willa Cather Memorial Prairie in terms of the characterizing species and types of vegetation. At each of 100 sample stand locations data were obtained on the 244-ha prairie in Webster County, Nebraska, to estimate percent basal cover and percent species composition. Estimates were analyzed quantitatively with the aid of vegetation ordination techniques, from which 15 vegetation types were discerned. Of the 15 types, two accounted for over $\mathbf{4 0 \%}$ of the stands: a Kentucky bluegrass (Poa pratensis)buffalograss (Buchloe dactyloides)-blue grama (Bouteloua gracilis)-type and a Kentucky bluegrass-sideoats grama (Bouteloua curtipendula)-big bluestem (Andropogon gerardi) type. Two secondary types accounted for another $16 \%$ of the stands, while the remaining $44 \%$ of the stands were fairly evenly dispersed within nine other types. Uplands were predominately Kentucky bluegrass, buffalograss, blue grama, and Japanese brome. Sideoats grama, little bluestem (Andropogon scoparius), and Kentucky bluegrass dominated hillside stands. Most abundant in lowlands were Kentucky bluegrass, sideoats grama, Japanese brome, and big bluestem. Due to the abundance of Kentucky bluegrass, late spring burning was prescribed to improve the condition and productivity of the prairie.
\end{abstract}

The continuum concept of vegetation has the premise that "communities occurring along continuous environmental gradients change continuously with gradual change in the density of each species"' (Poole 1974). The above idea was expressed by Ramenskylin 1910 (Sobolev and Utekhim, in Whittaker 1973). However, Gleason (1917, 1929, and 1939) was the first strong advocate of the continuum, or individualistic concept.

Most ecologists reportedly accept the continuum concept (Poole 1974); however, others envision communities to be sufficiently distinct from one another that they can be thought of as quasi-organism (Clements 1916; Tansley 1920). A somewhat more modulated view of communities recognizes that discernible community zones exist, while the flora of the earth exhibits a continuum (Daubenmire 1966). The placement of vegetation stands into classes has been referred to as the classification concept.

Among the first to base research on the continuum concept were Curtis and McIntosh (1951), Brown and Curtis (1952),

Authors are associate professor of botany, Fort Hays State University, Hays, Kansas 67601 ; and range conservationist, Bureau of Indian Affairs, Eagle Butte, South Dakota 57625

This rescarch was financially supported primarily by a grant from Woods Charitable Foundation through the Midwest Office of the Nature Conservancy, Minneapolis, Minnesota. Additional renumeration was also received from the Research Committee of the Graduate Council and the Department of Biological Sciences, Fort Hays State University, Hays Kans.

Manuscript received July 11, 1977
Whittaker (1956, 1967), and Goodall (1963) in which some form of ordination was utilized. Ordination of vegetation was apparently first defined by Goodall (1954) as an arrangement of species or stands in a uni- or multidimensional order by individual values. Ordination may also be defined as "the arrangement of ecological entities in a spatial model with a relatively small number of axes, in order to reflect the relationships between these entities in terms of the variables characterizing them" (Maarel 1969). In practice the divergence between classification and ordination is not great (Greig-Smith 1964).

Various ordination techniques may be utilized to arrange species or stands either directly or indirectly along an axis. The techniques used herein were of the indirect category, and information from the ordination procedures was used to order the stands, then classify them into types as connoted by the definition of Maarel (1969).

The area of study consisted of a 244-ha tract of Mixed Prairie located in the loessial region of south-central Nebraska (T.1N, R $11 \mathrm{~W}$, Sec. 35; $9.6 \mathrm{~km}$ south of Red Cloud, Webster County). It is bordered on the south by the Kansas state line and on the east by U.S. Highway 281. The Willa Cather Memorial Prairie consists of uplands that vary from level and gently sloping to steep topography on deep, silty soils, that developed from material derived from chalky limestone. The Geary-HoldregeKipson is the major soil association. Weaver and Bruner (1948) and Hopkins (1951) studied the vegetation of the loess hills in the central part of Nebraska. Remnant vegetation of the loessial region in southern Nebraska was characterized by Hulett et al. (1968) and Nicholson and Hulett (1969).

The Soil Conservation Service was àsked to perform a range inventory in June 1976 in which two range sites were classified: silty (120 ha) and shallow limy (124). Range conditions for the silty and shallow limy sites were conservatively rated at 1.1 AUM/ha (fair) and 1.2 AUM/ha (good), respectively, for a total carrying capacity of 281 AUM.

Arithmetic means were calculated from weather data obtained between 1921 and 1950 at Red Cloud, Nebraska (National Oceanic and Atmospheric Administration 1974). The mean monthly low temperature of $-3.2^{\circ} \mathrm{C}$ occurs in January; the mean monthly high temperature of $26.6^{\circ} \mathrm{C}$ occurs in July. The mean annual temperature and precipitation are $11.7^{\circ}$ and 58.37 $\mathrm{cm}$, respectively. June is the month with the highest mean monthly precipitation total, with $10.16 \mathrm{~cm}$; January has the least monthly mean with $1.47 \mathrm{~cm}$. The most frequent date of last spring freeze is May 1, whereas the first fall freeze is most often October 4; thus the mean growing season is 156 days. 
In 1974 , the study area was purchased by the Nature Conservancy as a memorial to Willa Carther; and during the 1975 and 1976 seasons, livestock grazing was discontinued. This study and several others were conducted to establish baseline ecological data to aid in future management and to allow documentation of vegetation changes. Resampling is tentatively scheduled for 1980 , following several seasons of grazing, burning, and rest.

\section{Methods}

Field sampling encompassed mid-May through August 1975. Using the modified step-point method of Owensby (1973), 150 step-points were taken to obtain percent of basal cover and percent species composition at each of 100 stand locations.

Three different vegetation ordination techniques were initially utilized in this study (Marcotte 1976 a). These included the polar ordination (PO) technique of Bray and Curtis (1957); geometric ordination of Swan et al (1969); and principal component ordination (PCO) of Goodall (1954), Dagnalie (1960), Orloci (1966), Austin (1968), and others. For each of the three ordination techniques, one ordination based on percent species composition and one based on percent basal cover were performed. Values for the 18 most important species ( $>0.3 \%$ species composition) were utilized as variables in the ordination procedures; hence the original data matrix was 18 by 100 . Although intermediate results of the different kinds of ordinations were similar, species composition values using the polar ordination technique were judged most efficient; therefore vegetative interpretations reported herein were based solely upon the polar ordination. Gauch and Whittaker (1972), in a study comparing such techniques, advise the use of polar ordination because of its inherent accuracy and simplicity.

All numerical procedures were preformed on an IBM 370/125 at Fort Hays State University Data Processing Center. For the polar ordination, a FORTRAN program-SIMCORD-was written (Marcottc 1976 b). Gcomctric ordination was computed with the FORTRAN program SDWORD (Hoag 1971). The FORTRAN program BMD01M was used for computing principal components (Dixon 1971).

Nomenclature used for the grasses was according to Hitchcock (1950), while Fernald (1950) was used for forbs. Voucher specimens were obtained and are on file in the Kearney Nebraska State College Herbarium (Dr. Ole Kolstad, Curator).

\section{Results}

Mean percent species composition for each of the 18 most important species over the entire area was calculated (Table 1). Kentucky bluegrass was the commonest of the seven most abundant grasses, followed by sideoats grama. Other species in descending order were: Japanese brome, buffalograss, little bluestem, blue grama, and big bluestem.

Species composition values for individual species were plotted on their respective stand locations on the ordination plane, one being drawn for each of the seven most abundant species of grasses. Each plane was then bisected with a single line, as straight as possible, so that stands with values greater than 10 were to one side of the line while stands less than 10 were to the other (Fig. 1). The tendency of certain stands to form such groups served as an objective basis for the classification of the stands into vegetation types. Intersecting bisect lines formed the boundaries of types on the ordination plane. From a practical point-of-view, this simplified the analysis of the vegetation and aided in visualizing ecological relationships. Means of species in the high and low sides of the bisect lines were calculated (Table 2). Using the bisect method, two primary, three secondary, and ten tertiary vegetation types were found. Of the ten tertiary types, one type had only one stand and two were
Table 1. Eighteen herbaceous species used in the data analysis.

\begin{tabular}{|c|c|c|}
\hline $\begin{array}{c}\text { Species } \\
\text { common name }\end{array}$ & $\begin{array}{c}\text { Species } \\
\text { scientific name }\end{array}$ & $\begin{array}{c}\text { Mean } \\
\% \text { sp comp }\end{array}$ \\
\hline Kentucky hluegrass & Poa pratensis & 27.6 \\
\hline Sideoats grama & Bouteloua curtipendula & 17.7 \\
\hline Japanese brome & Bromus japonicus & 8.6 \\
\hline Buffalograss & Buchloe dactyloides & 8.6 \\
\hline Little bluestem & Andropogon scoparius & 7.2 \\
\hline Blue grama & Bouteloua gracilis & 6.2 \\
\hline Big bluestem & Andropogon gerardi & 5.5 \\
\hline Sedges & Carex species & 2.8 \\
\hline Tall dropseed & Sporobolus asper & 2.5 \\
\hline Western ragweed & Ambrosia psilostachya & 2.1 \\
\hline Scribner panicum & Panicum scribnerianum & 1.5 \\
\hline Hairy grama & Bouteloua hirsuta & 1.4 \\
\hline Western wheatgrass & Agropyron smithii & 1.4 \\
\hline Missouri goldenrod & Solidago missouriensis & 0.8 \\
\hline Field pussytoes & Antennaria neglecta & 0.6 \\
\hline Sand dropseed & Sporobolus cryptandrus & 0.5 \\
\hline Louisiana sagewort & Artemisia ludoviciana & 0.3 \\
\hline Slimflower scurfpea & $P_{\text {soralea tenuiflora }}$ & 0.3 \\
\hline
\end{tabular}

imaginary (Fig. 1). The mean species composition values for each of the most common forage species were calculated for each of the vegetation types; however a simplified form of the table was constructed to further clarify the character of the vegetation (Table 3). Six types were dominated by four of the seven species, seven types by three species, and two by two.

Types one through five contained stands in which the mean of the composition values for the bluc grama was high (13.5\%), while below the bisect line that separated blue grama types from the remainder of the stands, the mean for blue grama (3.3\%) was low (Fig. 1, Table 2). Type one represented the extremes of both ordination axes and was predominately Kentucky bluegrass, buffalograss, and blue grama (Table 3 ). Type two, which was not found on the prairie, would have had a fourth dominant, sideoats grama, in addition to those of type one. Type three, also imaginary, was small and different from type two in that big bluestem would have replaced buffalograss. Type four was represented by only one stand in a small area of ordination. Types four, five, and six were defined by a bisect line that represented the stands with low values of Kentucky bluegrass,

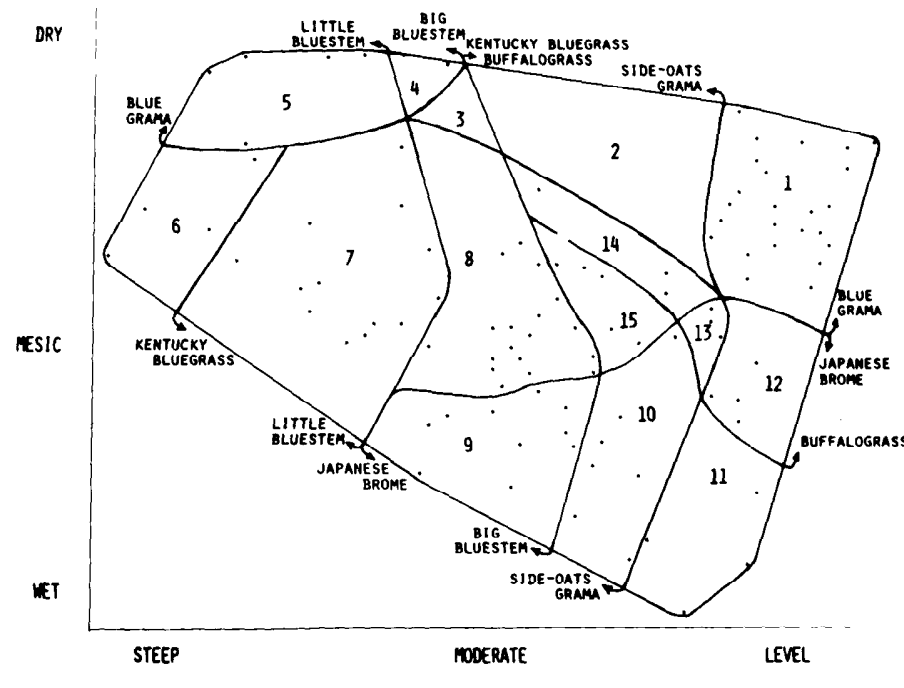

Fig. 1. Vegetation types are numbered 1-15. Dots indicate locations of 100 sample stands on the $X$ (horizontal), $Y$ (vertical) ordination. Bisect lines terminate with arrow directed toward the "high" side of the line and the species indicated. Levels of environmental gradients are indicated on ordination axes. 
Table 2. Mean species composition values for stands on high and low sides of ordination bisect lines.

\begin{tabular}{|c|c|c|c|c|c|c|c|}
\hline $\begin{array}{c}\% \\
\text { comp. }\end{array}$ & $\begin{array}{c}\text { Big } \\
\text { bluestem }\end{array}$ & $\begin{array}{l}\text { Little } \\
\text { bluestem }\end{array}$ & $\begin{array}{l}\text { Sideoats } \\
\text { grama }\end{array}$ & $\begin{array}{l}\text { Blue } \\
\text { grama }\end{array}$ & $\begin{array}{c}\text { Japanese } \\
\text { brome }\end{array}$ & $\begin{array}{c}\text { Buffalo- } \\
\text { grass }\end{array}$ & $\begin{array}{l}\text { Kentucky } \\
\text { bluegrass }\end{array}$ \\
\hline High & 9.7 & 23.3 & 23.6 & 13.5 & 17.6 & 19.2 & 30.2 \\
\hline Low & 1.1 & 2.8 & 5.7 & 3.3 & 5.4 & 2.6 & 2.9 \\
\hline
\end{tabular}

while the mean for the stands to the right of the line was high. Type six represented the low extreme of the $\mathrm{X}$-axis, and the left-most stand located there had the highest value of little bluestem of any stand.

Stands in types five, six, and seven had a high mean for little bluestem, while to their right, the mean of the remaining stands was low (Fig. 1 and Table 2). Big bluestem was found in abundance in types three through nine. In addition to big bluestem, types seven, eight, and nine were dominated by Kentucky bluegrass and sideoats grama. Japanese brome was abundant in types nine through 13; the top-most limit of these types was the bisect line for Japanese brome. The lower-most stand of the ordination plane was a stand that had the highest value for Japanese brome. Types 11,12 , and 1 were the only types in which sideoats grama composition was low. The area defining buffalograss abundance included types 1,2, 12, 13, and 14 (Fig. 1, Tables 2 and 3).

Lines were also drawn on an ordination surface to illustrate groups of like topographic class: (1) upland, (2) hillside, and (3) lowland (Fig. 2). Upland stands tended to be most homogenous, while lowland and hillside stands were more scattered on the ordination surface, indicating a wider variety of types of vegetation in those classes. Superimposition of the topographic ordination (Fig. 2) over the types of vegetation (Fig. 1) revealed the relationships of the vegetation types to the topography.

\section{Discussion}

Types one and eight were called the primary vegetation types of Willa Cather Memorial Prairie, representing 43 of the 100 stands. The two types were quite different from one-another; however, but both had a high mean value of Kentucky bluegrass $(>30 \%)$. On the plot of topographic classes, it was found that type one was exclusively found on the uplands and could

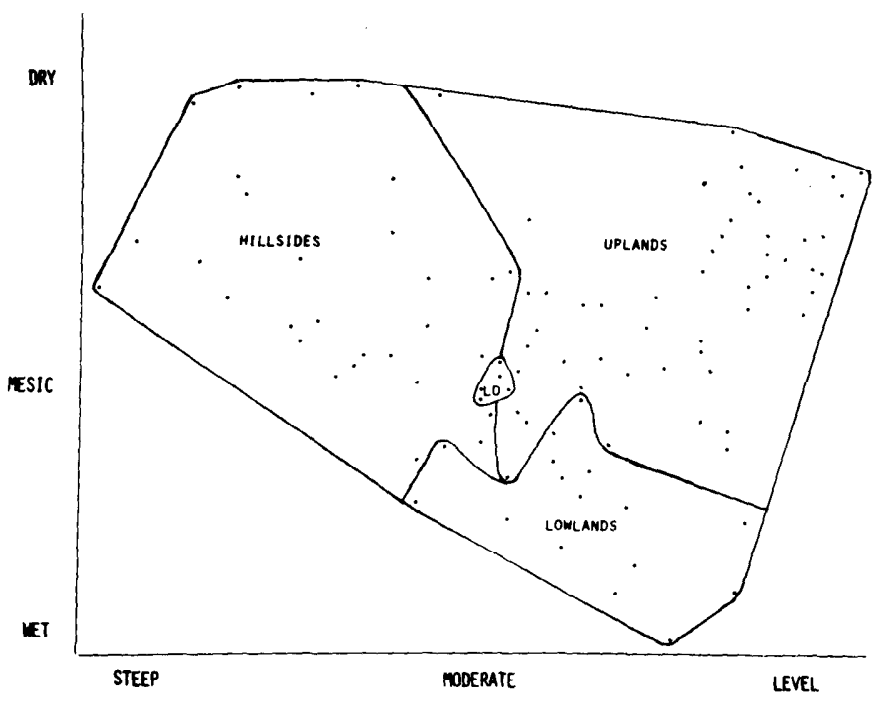

Fig. 2. Topographic classes of stands are indicted on ordination surface. Categories of environmental gradients are indicated on ordination axes.

therefore be expected to best characterize upland vegetation. Conversely, type eight had about equal numbers of stands in all three topographic classes.

The plot of topographic classes allowed hypothesizing underlying environmental gradients for the first two ordination axes (Fig. 1 and 2). The horizontal axis was assumed to represent a slope gradient, the vertical axis a soil water gradient. The driest, flattest stands were to the upper right, in the general position of type one. Dry, steep sites were to the upper left, while wet, steep sites were irrational and naturally not encountered in the sampling. Level, wet sites described conditions of lowland sites and corresponded to types 8 through 11 . As would be expected with any normally dispersed variable, most stands fell near the center of the ordination plane, i.e. average of intermediates with respect to environmental conditions.

Upland sites in the Mixed Prairie ordinarily are dominated by blue grama and buffalograss, with blue grama normally much more abundant (Albertson 1937, Weaver and Alberston 1956, Weaver and Bruner 1948, and Weaver 1965). In a study, of remnant grasslands in the loessial region of southern Nebraska, Hulett et al. (1968) found the upland dominated by blue grama and big bluestem. The Willa Cather Prairie has a history of

Table 3. Vegetation types discerned from the ordination analysis vs high mean $(+)$ or low mean $(-)$ of the seven most abundant grasses.

\begin{tabular}{|c|c|c|c|c|c|c|c|c|}
\hline Type & $\begin{array}{c}\text { Big } \\
\text { bluestem }\end{array}$ & $\begin{array}{c}\text { Little } \\
\text { bluestem }\end{array}$ & $\begin{array}{c}\text { Sideoats } \\
\text { grama }\end{array}$ & $\begin{array}{l}\text { Blue } \\
\text { grama }\end{array}$ & $\begin{array}{l}\text { Japanese } \\
\text { brome }\end{array}$ & $\begin{array}{c}\text { Buffalo- } \\
\text { grass }\end{array}$ & $\begin{array}{l}\text { Kentucky } \\
\text { bluegrass }\end{array}$ & $\begin{array}{l}\text { No. } \\
\text { stands }\end{array}$ \\
\hline 1 & - & - & - & + & - & + & + & 24 \\
\hline 2 & - & - & + & + & - & + & + & 0 \\
\hline 3 & + & - & + & + & - & - & + & 0 \\
\hline 4 & + & - & + & + & - & - & - & 1 \\
\hline 5 & + & + & + & + & - & - & - & 4 \\
\hline 6 & + & + & + & - & - & - & - & 4 \\
\hline 7 & + & + & + & - & - & - & + & 13 \\
\hline 8 & + & - & + & - & - & - & + & 20 \\
\hline 9 & + & - & + & - & + & - & + & 10 \\
\hline 10 & - & - & + & - & + & - & + & 8 \\
\hline 11 & - & - & - & - & + & - & + & 4 \\
\hline 12 & - & - & - & - & + & + & + & 3 \\
\hline 13 & - & -. & + & - & - & + & + & 3 \\
\hline 14 & - & - & + & - & - & + & + & 3 \\
\hline 15 & - & - & + & - & - & - & + & 3 \\
\hline
\end{tabular}


overgrazing, which may account for the abundance of Kentucky bluegrass, the presence of Japanese brome, and the greater abundance of buffalograss than of blue grama. Kentucky bluegrass increases under heavy grazing and annual bromegrasses invade, whereas buffalograss may increase and blue grama would be expected to decrease (Branson and Weaver 1953; Weaver 1968). In a study of ungrazed remnant vegetation in the loessial plains region, Nicholson and Hulett (1969) found the following mean percent species composition values for the following species: Kentucky bluegrass -0.0 ; sideoats grama19.0; Japanese brome-0.0; buffalograss-3.0; little bluestem-17.2; blue grama- 5.8 ; and big bluestem-39.0. Presumably, grazing is the main factor that is responsible for differences between the Willa Cather stands and the prairie remnants. The lowland types tended to be characterized by abundant Kentucky bluegrass, sideoats grama, big bluestem, and Japanese brome (Fig. 1 and 2). Lowland sites in Mixed Prairie have been reported to be dominated by big bluestem, sideoats grama, and western wheatgrass (Weaver and Bruner 1948; Weaver and Albertson 1956). An understory of Kentucky bluegrass may also be encountered (Weaver 1965). Hulett et al. (1968) found similar lowland components in their study of remnant grasslands. According to Branson and Weaver (1953), the loessial lowlands are the most preferred of all grazing sites. This preference was attributed partly to the abundance of big bluestem and partly to the succulence of vegetation occurring there.

Hillsides were generally not lacking in Kentucky bluegrass except due to insufficient soil water (Fig. 1 and 2). Blue grama appeared not to be slope limited, but buffalograss, little bluestem, big bluestem, and sideoats grama did. Japanese brome appeared soil water limited as did blue grama and buffalograss, while to a lesser extent this was true for Kentucky bluegrass, big and little bluestem. The lines that define the types with abundances of big and little bluestem and sideoats grama are relatively parallel and vertical. Big bluestem exhibited a relatively narrow tolerance range on the slope axis and a wider range in the soil water axis, although a few dry stands had an abundance of big bluestem. The line defining blue grama abundance tended to be more parallel with the slope axis; however, most stands of blue grama were on the level, few were on the steep slopes, and none were on the moderate slopes or wet sites.

Little bluestem seemed to be limited to the drier, steeper slopes. Before the great drought of 1933-1940, little bluestem and sideoats grama were dominant on hillside sites (Albertson 1937, Weaver 1965). The drought resulted in hillside sites which were predominantly sideoats grama, big bluestem, (which reportedly replaced little bluestem), little bluestem, and blue grama (Weaver and Bruner 1948, Weaver and Albertson 1956). In their remnant grassland study, Hulett et al. (1968) found the hillside compositions dominated by sideoats grama, little bluestem, blue grama, and big bluestem. Hulett and Tomanek (1969), in a study of remnant prairies on shallow limy range sites in north-central Kansas, found little bluestem to be the most abundant species, followed by big bluestem and sideoats grama. The shallow limy range site often has relatively steep slopes and therefore calcareousness of surface soils would probably be positively correlated with slope. However, not all steep slopes sampled were shallow limy.

Important hillside species in the Willa Cather Prairic corresponded to those found in the above studies, except for the abundance of Kentucky bluegrass. This may indicate that, although Kentucky bluegrass has increased as a result of improper grazing, it is not as abundant on the hillside as on the upland. The original species compositions of the hillsides have apparently been maintained due to the preference of cattle to graze more level sites.

Types two and three, which were imaginary, were conspicuous in that no stands were located there. Apparently such an association could not occur due to environmental or interspecific limits. This was surprising, in that area on the ordination allotted to the imaginary type two was rather large, hence allowing a reasonable probability that a stand could occur there. Environmentally, types two and three were considered rational, yet no stands were found in the sampling that were located on dry, moderate slopes (Fig. 1 and 2). Moderate slopes tended to be more mesic while the most level and most steep slopes were drier.

\section{Literature Cited}

Anderson, K.L., E.F. Smith, and C.E. Owensby. 1970. Burning bluestem range. J. Range Manage. 23:81-92.

Albertson, F.W. 1937. Ecology of mixed prairie in west central Kansas. Ecol. Monog. 7:481-547.

Austin, M.P. 1968. An ordination study of chalk grassland community. J. Ecol. 56:739-757

Branson, F.W., and J.E. Weaver. 1953. Quantitative study of degeneration of mixed prairie. Bot. Gaz. 114:397-416.

Bray, J.R., and J.T. Curtis. 1957. An ordination of the upland forest communities of southern Wisconsin. Ecol. Monog. 27:325-349.

Brown, R.T., and J.T. Curtis. 1952. Upland conifer-hardwood forest of northern Wisconsin. Ecol. Monog. 22:217-234.

Clements, F.E. 1916. Plant succession: an analysis of the development of vegetation. Pub. Carneg. Inst. 242.

Curtis, J.T., and R.P. McIntosh. 1951. An upland forest continuum in the prairie-forest border region of Wisconsin. Ecology 32:476-496.

Dagnelie, P. 1960. Contribution à l'étude des communautés végétales par l'analyse factorielle. (Engl. summ.) Bull. Serv. Carte Phytogéogr., Sér. B, 5:7-71, 93-195.

Daubenmire, R. 1966. Vegetation: Identification of typal communities. Science 151:291-298.

Dixon, W.J., ed. 1971. Biomedical Computer Programs. U. of California Press, Berkeley. 600 p.

Fernald, M.L. 1950. Gray's Manual of Botany. American Bonk Co., New York. $1632 \mathrm{p}$.

Gauch, H.G., and R.H. Whittaker. 1972. Comparison of ordination techniques. Ecology 53:868-875.

Gleason, H.A. 1917. The structure and development of the plant association. Bull. Torrey Bot. Cl. 43:463-481.

Gleason, H.A. 1929. Plant associations and their classification: A reply to Dr. Nichols. Internatl. Cong. Plant Sci., Ithaca, Proc. 1:643-646.

Gleason, H.A. 1939. The individualistic concept of the plant association. Amer. Midl. Natur. 21:92-110.

Goodall, D.W. 1954. Objective methods for the classification of vegetation. III. An essay in the use of factor analysis. Austral. J. Bot. 2:304-324.

Goodall, D.W. 1963. The continuum and the individualistic association. Vegetatio 11:297-316.

Greig-Smith, P. 1964. Quantitative Plant Ecology. Butterworth and Co. Ltd., London. $256 \mathrm{p}$.

Hitchcock, A.S. 1950. Manual of the Grasses of the United States. U.S.D.A., Misc. Pub. 200. 1051 p.

Hoag, M. 1971. SDWORD user's handbook-version 3. Comp. Center, North Dakota State Univ., Fargo. 15 p.

Hopkins, H.H. 1951. Ecology of the native vegetation of the loess hills in central Nebraska. Ecol. Monog. 21:125-147.

Hulett, G.K., C.D. Sloan, and G.W. Tomanek. 1968. The vegetation of remnant grasslands in the loessial region of northwestern Kansas and southwestern Nebraska. Southwestern Natur. 13:377-391.

Hulett, G.K., and G.W. Tomanek, 1969. Remnant prairie on the shallow limy range site in north central Kansas. J. Range Manage. 22:19-23.

Maarel, E. Vander. 1969. On the use of ordination models in phytosociology. Vegetatio 19:21-46.

Marcotte, M.G. 1976 a. Vegetation ordination and computer mapping of a prairie in south-central Nebraska. MS Thesis, Fort Hays Kansas State College, Hays $78 \mathrm{p}$. 
Marcotte, M.G. 1976 b. User's manual to SIMCORD. Proc. Dep. Biol., Fort Hays Kansas State College, Hays.

Nicholson, R.A., and G.K. Hulett. 1969. Remnant grassland vegetation in the central Great Plains of North America. J. Ecol. 57:599-612.

National Oceanic and Atmospheric Administration. 1974. Climates of the states. Water Information Center, Inc., Port Washington, New York. 975 p.

Orloci, L. 1966. Geometric models of ecology. I. The theory and application of some ordination models. J. Ecol. 54:193-215.

Owensby, C.E. 1973. Modified step-point system for botanical composition and basal cover estimates. J. Range Manage. 26:302-303.

Owensby, C.E. 1975. Range burning results. Pages 13-19. In: H. Jones, ed. Bluestem Range Management Clinic. Rep. of Prog. No. 244. Agr. Exp. Sta., Kansas State Univ., Manhattan.

Owensby, C.E. 1978. Intensive-early stocking and season-long stocking of Kansas Flint Hills Range. J. Range Manage. 31:14-17.

Poole, R.W. 1974. An Introduction to Quantitative Ecology. McGraw-Hill, Inc., New York. 532 p.

Sobolev, L.N., and V.D. Utekin. 1973. Russian (Ramensky) approaches to community systematization. Pages 75-103. In: R. Tüxen, ed. Handbook of Vegetation Science, Part V: Ordination and classification of communities, R.H. Whittaker, ed. Junk, The Hague.
Swan, J.M.A., R.L. Dix, and C.F. Wehrhahn. 1969. An ordination technique based on the best possible stand-defined axes and its application to vegetational analysis. Ecology 50:206-212.

Tansley, A.G. 1920. The classification of vegetation and the concept of development. J. Ecol., 8:118-149.

Weaver, J.E. 1965. Native vegetation of Nebraska. Univ. of Nebraska Press, Lincoln. $185 \mathrm{p}$.

Weaver, J.E. 1968. Prairie Plants and Their Environment. Univ of Nebraska Press, Lincoln. 276 p.

Weaver, J.E., and W.E. Bruner. 1948. Prairies and pastures of the dissected loess plains of central Nebraska. Ecol. Monog. 18:507-549.

Weaver, J.E., and F.W. Albertson. 1956. Grasslands of the Great Plains. Johnson Publishing Co., Lincoln, Nebraska. 395 p.

Whittaker, R.H. 1956. Vegetation of the Great Smoky Mountains. Ecol. Monog. 26:1-80.

Whittaker, R.H. 1967. Gradient analysis of vegetation. Biol. Rev. 42:207264.

Whittaker, R.H. 1973. Introduction. Pages 1-6 In: R. Tüxen, ed. Handbook of Vegetation Science, Part V: Ordination and classification of communities, R.H. Whittaker, ed. Junk, The Hague.

\section{Certification of Range Management Consultants}

Applications must be submitted by October 1, 1979 , to be considered for certification in 1980 . Applications Forms and Procedures for Certification in 1980 are available by request to the Executive Secretary. The Procedures have been revised, especially to include more detail on eligibility requirements, and published in the April issue of Rangelands. The Certification Panel welcomes suggestions for further revision, which should be sent to the Executive Secretary. 